\title{
New insights from animal models of colon cancer: inflammation control as a new facet on the tumor suppressor APC gem
}

This article was published in the following Dove Press journal:

Gastrointestinal Cancer: Targets and Therapy

30 January 2015

Number of times this article has been viewed

\author{
Maged Zeineldin \\ Kristi L Neufeld \\ Department of Molecular \\ Biosciences, University of Kansas, \\ Lawrence, KS, USA
}

Correspondence: Kristi L Neufeld Department of Molecular Biosciences, University of Kansas, 7049 Haworth Hall, I 200 Sunnyside Avenue, Lawrence, KS 66045, USA

Tel +l 7858645079

Fax +I 7858645294

Email klneuf@ku.edu

\begin{abstract}
Colorectal cancer (CRC) is one of the most common causes of cancer-related deaths worldwide. As with other cancers, CRC is a genetic disease, however, several risk factors including diet and chronic colitis predispose to the disease. Mutations in the tumor suppressor adenomatous polyposis coli $(A P C)$ initiate most cases of CRC. Recent data from mouse models suggest that $A P C$ mutations and colitis are not completely independent factors in colorectal carcinogenesis. Here, we review the evidence supporting an interaction between APC mutations and chronic colitis. We will also discuss possible pathophysiologic mechanisms behind this interaction.
\end{abstract}

Keywords: rodent model, colon cancer, adenomatous polyposis coli, APC, tumor suppressor, inflammatory bowel disease

\section{Introduction}

Colorectal cancer (CRC) is the fourth largest cancer killer worldwide and accounts for about $9 \%$ of cancer related deaths in the Unites States. ${ }^{1}$ CRC is a genetic disease that results from accumulation of mutations in tumor suppressor genes and proto-oncogenes. ${ }^{2}$ There are many factors that increase CRC risk, including age, diet, ethnic background, known genetic alterations, family history of the disease, and chronic colon inflammation (colitis). ${ }^{3}$ Mouse and rat models developed to study CRC have confirmed some of the risk factors elucidated from human cases. These models also revealed many of the molecular events underlying different risk factors and interactions between various risk factors. ${ }^{4,5}$ In this review we will discuss the interaction between the most common genetic alteration in $\mathrm{CRC}$, mutations in the tumor suppressor $A P C$, and a major predisposing factor for $\mathrm{CRC}$, chronic colitis, as illuminated by studies of rodent models.

\section{APC structure, functions, Wht signaling}

Mutations in $A P C$ are the most prevalent among genetic alterations found in CRC. ${ }^{6}$ These $A P C$ mutations occur early during CRC tumorigenesis and are considered the initiating events of $\mathrm{CRC}{ }^{2}$ In addition to the frequent somatic $A P C$ mutations, a more rare inheritance of a germline $A P C$ mutation in familial adenomatous polyposis (FAP) patients leads to development of tens to thousands of colonic adenomatous polyps. ${ }^{7,8}$ Although benign, these polyps have, on average, a $1 \%-5 \%$ chance of undergoing malignant transformation. Considering the number of polyps that typically develop in FAP patients, CRC is nearly inevitable, unless the colon is surgically resected. ${ }^{9}$ 
The $A P C$ gene encodes a large multidomain protein, 2,843 amino acids, that interacts with many other proteins and is implicated in multiple cellular processes. ${ }^{10,11}$ The most characterized function of APC is to antagonize Wnt signaling-induced cellular proliferation by destroying the oncoprotein $\beta$-catenin. ${ }^{12} \mathrm{APC}$ is a component of a multiprotein cytoplasmic complex that phosphorylates and targets $\beta$-catenin for proteasome-mediated degradation. In the presence of Wnt ligand, or in the absence of functional APC, $\beta$-catenin accumulates in the cytoplasm and translocates to the nucleus, where it binds to the transcriptional cofactor $\mathrm{TCF} / \mathrm{LEF}$ to alter the expression of Wnt target genes. ${ }^{13}$ Most $\beta$-catenin-responsive genes are induced eg, MYC, CyclinD1, and $A X I N 2$; and a minority are downregulated, eg, $H A T H 1^{14-17}$ (for an updated list of Wnt target genes see the Wnt homepage http://www.stanford.edu/group/nusselab/cgi-bin/wnt/ target_genes).

Wnt signaling plays an important role in maintaining the intestinal epithelial architecture. ${ }^{18}$ The intestine is lined by a single layer of columnar epithelial cells that are arranged in finger-like projections into the lumen (villi, only in the small intestine) and sac-like invaginations (crypts, in both the small and large intestines). Stromal cells at the crypt base secrete Wnt ligands that maintain a gradient Wnt concentration along the length of the crypt. Intestinal stem cells located at the crypt base (highest concentration of Wnt) divide to maintain the stem cell population and also produce progenitor transit amplifying cells (TA). ${ }^{19}$ TA cells further divide until they reach the upper one-third of the crypt (with lower Wnt concentration) where they start to differentiate into various adult cell types. ${ }^{13,20}$ The inability of mutant APC to antagonize Wnt signaling results in continuing proliferation, lack of differentiation, and intestinal tumor formation. ${ }^{21-23}$

Wnt-independent roles of APC include regulation of cellular adhesion, migration, cytoskeletal organization, spindle formation, cellular differentiation, and chromosome segregation. ${ }^{1024}$ APC coimmunoprecipitates with the adherens junction protein, $\beta$-catenin. ${ }^{25,26}$ Full-length, but not truncated, APC colocalizes with microtubules and also concentrates near the leading edge of migrating epithelial cells. ${ }^{27}$ This microtubule interaction involves the $\mathrm{C}$-terminal part of APC and is unrelated to Wnt antagonism. ${ }^{28} \mathrm{APC}$ interacts with the microtubule-associated protein $\mathrm{EB} 1^{29,30}$ and with the intermediate filament proteins Lamin B1 and Keratin 81 in cultured cells. ${ }^{31}$ Mutations in $A P C$ have been associated with chromosomal instability in both colon cancer cell lines and mouse embryonic stem cells. ${ }^{24,32}$ Moreover, in mouse intestinal epithelial cells, $A p c$ mutations affect the sensitivity of cultured cells to microtubule poisons, inhibiting spindle assembly checkpoint-induced mitotic arrest in response to low doses of microtubule poisons. ${ }^{33}$

In addition to the cytoplasmic functions described above, APC moves between the cytoplasm and the nucleus. ${ }^{34-36}$ This nucleo-cytoplasmic shuttling is aided by two nuclear localization signals (NLS) in the C-terminal half of APC and five nuclear export signals. ${ }^{36,37}$ Nuclear APC can antagonize Wnt signaling by sequestering nuclear $\beta$-catenin from interaction with the TCF/LEF transcription factor. ${ }^{35,38}$

Other proposed functions for nuclear APC include DNA synthesis, cell cycle regulation, and DNA repair. ${ }^{36} \mathrm{APC}$ interacts with Topoisomerase II $\alpha$, an enzyme essential in DNA replication and cell cycle progression. ${ }^{39,40} \mathrm{APC}$ also interacts with PCNA, FEN- 1 , and polymerase- $\beta$, components of long patch-base excision repair (LP-BER) ${ }^{41-45}$ and affects CREB$\mathrm{C} / \mathrm{EBP}$ - mediated transcription. ${ }^{46}$ Although the significance is not completely understood, APC appears to directly interact with A/T-rich DNA sequences ${ }^{47}$ It is important to note that cancer-associated mutations in $A P C$ usually result in deletion of the $\mathrm{C}$-terminus of the protein, including several protein interaction domains and both NLS. ${ }^{48}$

\section{Modeling Apc in rodents}

To study APC biological functions in development and cancer, several mouse and rat models have been made. A more comprehensive review of these models are provided in other articles. ${ }^{4,5}$ Most of these models have mutations resulting in truncated Apc, with lengths ranging from complete deletion to deletion of only the $\mathrm{C}$-terminal 300 amino acids. Figure 1 shows protein products resulting from $A p c$ mutations in rodent models that will be discussed in this review. These models displayed some of the same phenotypes as patients with germ line mutations of $A P C .{ }^{5}$ Mice with Apc truncation involving at least the C-terminal half of Apc develop intestinal tumors, though the number of tumors does not correlate with the extent of truncation. ${ }^{4}$ As in FAP patients, Apc truncating mutations in these models are lethal in a homozygous state, and tumor development requires mutation or loss of the other (wild type) $A p c$ allele. ${ }^{5}$ Tumors from these mouse models resemble those found in patients at both the histological and molecular levels. ${ }^{49}$ However, the mouse tumors mainly develop in small intestine, whereas FAP patients harbor mostly colonic tumors. ${ }^{4}$ Rats with a mutation that truncates Apc at amino acid 1137 develop tumors in both the small and large intestine. ${ }^{50}$ In addition, unlike in humans, progression to carcinoma is not typically seen in most $A p c$ mutant mice, presumably because of their limited lifespan. ${ }^{51}$ There are also 


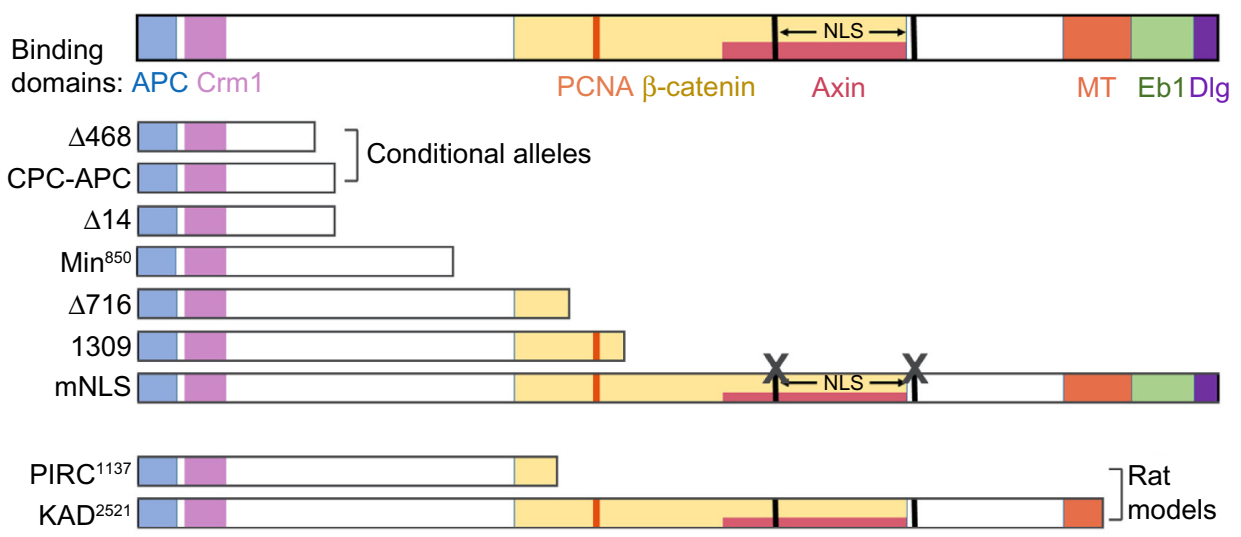

Figure I Apc mutant rodent models.

Notes: The 2,843 amino acid-long Apc protein with binding domains marked as follows: APC, homodimerization; Crm I/Exportin I binds NES to mediate nuclear export; PCNA (orange line), processivity factor for DNA polymerase $\delta$; Ebl, binds and regulates MT plus ends. Shown below the schematic are the Apc proteins from rodent models referenced in this review.

Abbreviations: PCNA, proliferating cell nuclear antigen; MT, microtubule; Eb I, end binding I; Dlg, discs large; NLS, nuclear localization signals.

some differences in the extraintestinal phenotypes in rodent Apc models and human FAP cases. ${ }^{4,5}$ Recently, several new $A p c$ rodent models have been generated to facilitate testing the function of a specific region or subcellular localization of Apc. These include a rat model with a shorter truncation (Apc $\mathrm{KAD}$ rat $),{ }^{52}$ and mouse models with interstitial mutations deleting a specific Apc domain $\left(\mathrm{Apc}^{\triangle \mathrm{SAMP}}\right)^{53}$ or disrupting Apc nuclear localization signals $\left(\mathrm{Apc}^{\mathrm{mNLS}}\right){ }^{54}$

In addition to rodent models with germ line $A p c$ mutations, several models use LoxP-Cre technology to delete all, or portions, of Apc in a conditional manner. ${ }^{5}$ In this system, deletion of a genomic region flanked by two LoxP1 sites is induced by expression of Cre recombinase enzyme. Cre-mediated deletion is specified by placing Cre under the control of a tissue-specific, developmental stage-specific, or drug-inducible promoter, or by infecting the tissue with adenovirus that expresses Cre recombinase. ${ }^{5} \mathrm{CPC}-\mathrm{APC}$, $\mathrm{Apc}^{580 \mathrm{D}}$, and $\mathrm{Apc}^{\triangle 468}$ are three such models discussed further in this review (Figure 1).

\section{Chronic colitis}

Besides APC mutations, other factors such as chronic inflammation increase risk of CRC. ${ }^{55}$ Inflammation is an immunological reaction to protect from harmful agents, including invading microorganisms. ${ }^{56,57}$ An estimated 15\% of all cancers are associated with chronic inflammation. ${ }^{58}$ For the colon, patients with an inflammatory bowel disease (IBD, ulcerative colitis, or Crohn's disease) have 2-4 times increased risk of CRC compared to the general population. ${ }^{55}$ This colitis-associated CRC is more aggressive and has a relatively poor prognosis. ${ }^{59}$ Many inflammatory mediators have roles in the protumorigenic effects of IBD-associated inflammation. ${ }^{55,59}$ These mediators are secreted by inflammatory as well as epithelial cells, and affect cellular survival, proliferation, apoptosis, and differentiation. ${ }^{55,59}$

\section{Modeling chronic colitis in rodents}

To facilitate studying colitis, a dextran sodium sulfate (DSS) model was developed in the rat and adapted to both hamster and mouse. ${ }^{60-63}$ In this model, colonic inflammation is usually induced by administration of DSS $(1 \%-4 \%)$ in drinking water for 3-7 days. Mice are then typically given untreated water for 2-4 weeks, with the cycle repeated up to four times. ${ }^{61}$

The DSS model appears similar to human ulcerative colitis at both the pathological and molecular levels. ${ }^{64}$ The pathological changes seen during the first DSS cycle in murine colons include loss of crypt structure and ulceration, symptoms that are also seen in the acute phase of the human disease. ${ }^{65}$ Following the first cycle, mucosal regeneration, crypt branching and shortening, glandular disorder, and diarrhea are also seen; these also occur in the chronic phase of ulcerative colitis in humans. As with human IBD, mice treated with DSS also show an increased incidence of colonic tumors that varies somewhat based on the protocol of DSS treatment. ${ }^{65,66}$ For Swiss mice treated with four cycles (7 days each) of $4 \%$ DSS, the colon tumor incidence is about $37.5 \%$ at 120 days and more than half of the lesions that develop in DSS-treated mice are flat, similar to those seen in the human disease. ${ }^{6}$ Some tumors in this model show malignant transformation. ${ }^{66}$ Molecular changes in tumors from DSS-treated mice also recapitulate those in human colitisassociated colorectal carcinogenesis. ${ }^{66,67}$

Administration of a mutagen increases the incidence of colonic tumors in the murine DSS model. ${ }^{64}$ The most 
commonly used mutagen is azoxymethane (AOM), which induces $\mathrm{O}^{6}$-methylguanine DNA adducts resulting in $\mathrm{G} \rightarrow \mathrm{A}$ transitions. ${ }^{64} \mathrm{~A}$ single intraperitoneal dose of AOM increases the incidence of colonic cancer in DSS-treated mice to $100 \%{ }^{64}$ Another advantage of including a mutagen in the protocol is that it allows reduction of the DSS dose in mice, and decreases the mortality from DSS-associated acute colitis. Again, different groups use different regimens of AOM treatment: single or multiple doses of $7.5-20 \mathrm{mg} / \mathrm{kg}$. A single AOM dose of $10 \mathrm{mg} / \mathrm{kg}$ alone without DSS treatment is not sufficient to induce tumors in wild-type mice. ${ }^{64}$

$\beta$-catenin mutations in exon 3 are detected in most tumors from AOM-DSS-treated mice. ${ }^{68}$ These mutations are expected to prevent phosphorylation and targeting of $\beta$-catenin for destruction, resulting in cellular accumulation and nuclear translocation of $\beta$-catenin, and promiscuous activation of Wnt signaling. ${ }^{68}$ On the other hand, many AOMinduced tumors in rats have $A p c$ mutations. ${ }^{69}$ Both mice and rats treated with AOM-DSS have activating mutations of the proto-oncogene, Kras, in later stage tumors. ${ }^{68} \mathrm{Wnt}$ and RAS pathways are typically activated in human CRC. ${ }^{2}$

\section{Intestinal epithelial barrier and gut microbiome}

Colon epithelial cells are exposed to a unique external environment. The colon lumen contains hard fecal matter, posing a potential threat of mechanical injury. ${ }^{70}$ In addition, the colon is inhabited by over one hundred trillion bacterial cells (almost ten times the number of cells in an adult human). These gut microbes consume organic materials and secrete various secondary metabolites. ${ }^{71,72}$ Intestinal epithelial cells have several lines of defense that prevent bacterial invasion or diffusion of harmful substances into the body while allowing absorption of nutrients and beneficial substances. ${ }^{73}$ These combined structural and physiological defenses are termed the "intestinal epithelial barrier". ${ }^{70,74}$

There are at least seven contributors to the intestinal epithelial barrier (Figure 2). First is the actual physical barrier created by mucus, which is continuously secreted by goblet cells. ${ }^{75}$ This mucus is formed of two layers; an outer loose layer and an inner adherent layer. The outer mucus lubricates the solid contents of the colon to prevent mechanical injury and also washes off microorganisms to prevent colonization.

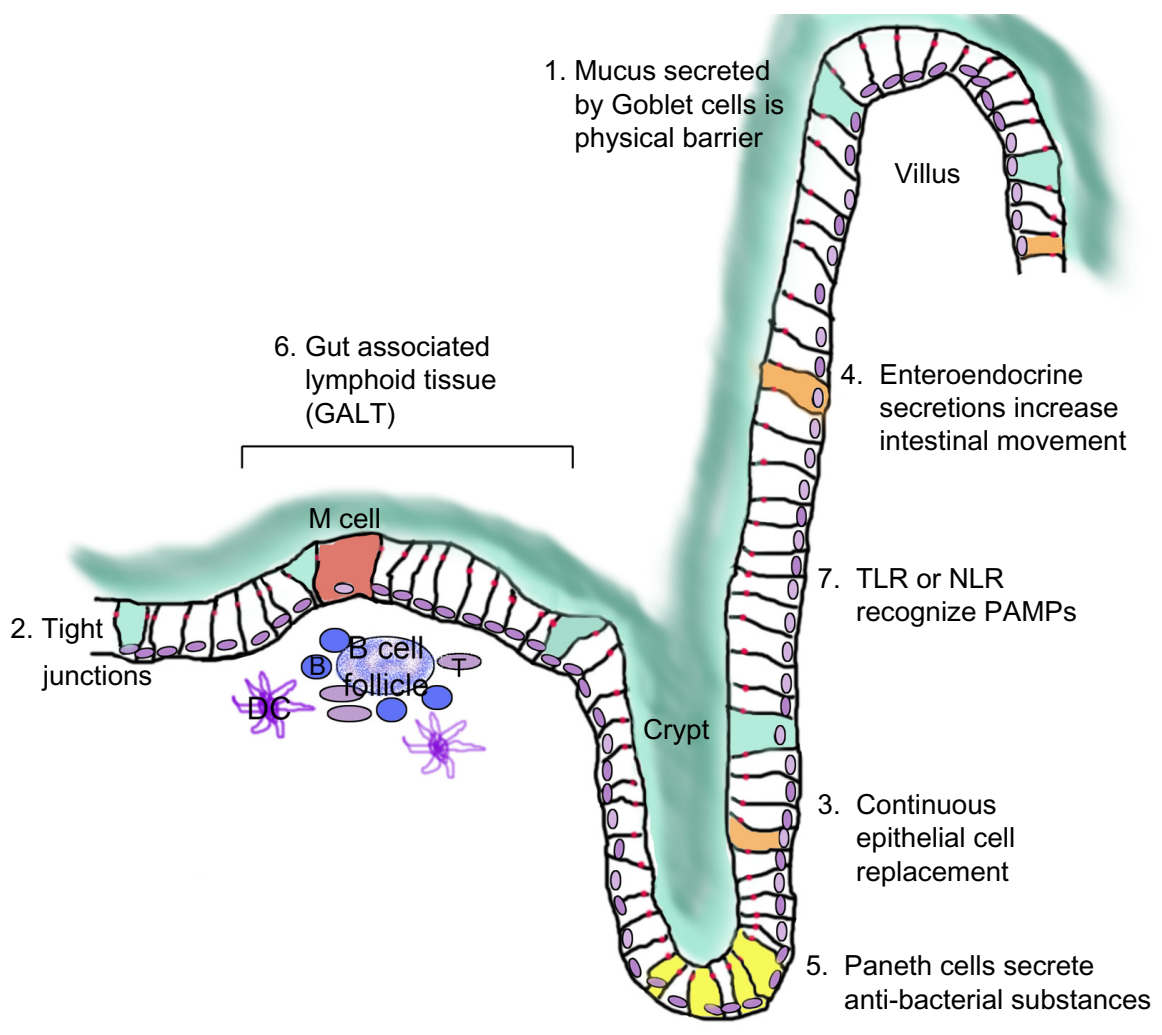

Figure 2 Intestinal epithelial barrier.

Notes: Protecting the body from invasion by intestinal microbes requires many layers of defense. This illustration depicts the small intestine. The colon would have similar components but lack Paneth cells and the villus structure. Goblet cells (green); tight junctions (red); enteroendocrine cells (orange); Paneth cells (yellow).

Abbreviations: DC, dendritic cell; T, T-cell; B, B-cell; TLR, Toll-like receptors; NLR, Nod-like receptors; PAMP, pathogen-associated molecular patterns. 
The inner mucus layer prevents contact of microorganisms and their products with the underlying epithelial cells. ${ }^{75}$ Second, epithelial cells lining the colon form a continuous sheet with tight junctions that further prevent flora and harmful molecules from penetration. ${ }^{76}$ Third, the continuous turnover of intestinal epithelial cells ensures rapid healing after any damage or ulceration..$^{70,77}$ Fourth, specialized epithelial cells, enteroendocrine cells, respond to bacterial invasion or toxic substances by secreting active amines to increase intestinal movement and fluid secretion, thereby washing off potential invaders. ${ }^{78}$ Fifth, in the small intestine, other specialized epithelial cells called Paneth cells secrete antibacterial substances. Sixth, intestinal tissue also contains aggregations of immune cells (gut-associated lymphoid tissues [GALT] and other immune cells) that can detect foreign antigens and defend the body against them. M-cells also contribute by engulfing antigens and bacteria from the lumen and transporting them to antigen presenting cells for immunological processing. ${ }^{70}$ Seventh, intestinal epithelial cells themselves detect different microbes and react to them by expressing receptors that can recognize pathogen-associated molecular patterns (PAMP) including Toll-like receptors (TLR) and Nod-like receptors (NLR). These receptors do not recognize specific antigens but specific molecular signatures associated with pathogens eg, methylated DNA and peptidoglycans. ${ }^{79}$

\section{Colitis and APC mutations}

$\mathrm{CRC}$ is fundamentally a genetic disease, the result of accumulated mutations in tumor suppressor genes and oncogenes. ${ }^{2}$ But the nature of the mutated genes and the order of their mutation can vary with different precipitating factors. ${ }^{67,80,81}$ Activation of Wnt signaling is seen in the vast majority of CRCs. ${ }^{2}$ Other signaling pathways that are commonly altered during CRC progression include activation of K-ras, p53, and TGF- $\beta .{ }^{82}$ Alterations in the same pathways are frequently seen in cases with colitis-associated CRC. In addition, activation of NF- $\kappa$ B and STAT3 pathways are also detected in colitisassociated CRC. The sequence and role of these pathway alterations in the development of $\mathrm{CRC}$ have been reviewed previously. ${ }^{59}$ Here, we will focus on genetic mutations of the tumor suppressor $A P C$.

Mutation of $A P C$ is by far the most common genetic event seen in CRC that leads to Wnt signal activation. Curiously, $A P C$ mutations are not detected in other Wnt-dependent tumors to nearly the same extent as seen in CRC. Rather, in non-colonic tumors, mutations in other Wnt components, are more commonly found, ${ }^{12}$ suggesting a colon-specific protective function of APC that is selected against during CRC development. Furthermore, data from AOM-DSS models suggest that Wnt signal activation alone is not sufficient for effective initiation of colon tumorigenesis. Injection of mice with a single dose of AOM, expected to induce oncogenic $\beta$-catenin mutations which activate Wnt signaling, results in no tumors or only a very low incidence of tumors. ${ }^{61,68}$ However, combing AOM with DSS-induced inflammation results in robust tumor formation. Moreover, patients and mice with germ line $A P C / A p c$ mutations develop intestinal tumors with $100 \%$ penetrance. ${ }^{5,9}$

The data supporting an association between $A P C$ mutations and inflammation are overwhelming. Inflammation can greatly increase intestinal tumorigenesis in rodent models with germ line $A p c$ mutations. DSS treatment of $A p c^{\mathrm{Min} /+}$ mice increases their colon tumor multiplicity by $15-30$-fold. ${ }^{83}$ Unlike AOM-induced tumors in wild-type mice treated with DSS, which show $\beta$-catenin stabilizing mutations, colonic tumors in DSS-treated $A p c^{\mathrm{Min} /+}$ mice typically show loss of the wild-type $A p c$ allele. ${ }^{83}$ The latter mechanism is similar to that seen in tumors from $\mathrm{Apc}^{\mathrm{Min} /+}$ mice not treated with DSS. ${ }^{84}$ Of note, the multiplicity of tumors in DSS-treated $A p c^{\mathrm{Min} /+}$ mice is higher than in wild-type mice treated with the mutagen AOM followed by DSS. ${ }^{83}$ Collectively, these data strongly support a colon-specific tumor suppressor function for APC beyond that as a Wnt signal antagonist, potentially to control colitis.

Experimental induction of inflammation in mouse intestinal tumor models by methods other than DSS administration also increases tumorigenesis. Germ line deletion of $\mathrm{Il}-10$ (an anti-inflammatory cytokines) or single immunoglobulin Il-1 receptor-related $(S I G I R R)$ molecule increases intestinal tumors in $A p c^{M i n /+}$ mice. ${ }^{85,86}$ Transgenic expression of $\mathrm{Il}-8$ (a proinflammatory cytokine) enhances tumorigenesis in both AOM-DSS and $A p c^{\mathrm{Min} /+}$ models. ${ }^{87}$ In addition, Nrf2 knockout mice display increased oxidative stress, increased inflammatory markers, and colitis and accelerated intestinal tumorigenesis. ${ }^{88,89}$ Conversely, reducing inflammation protects from intestinal tumorigenesis. Nonsteroidal anti-inflammatory drugs (NSAIDs) reduce polyp formation in FAP patients as well as in $A p c^{\mathrm{Min} / 4}, A p c^{\Delta 474 /+}$, and $A p c^{1309 /+}$ mouse models. ${ }^{90-94}$ Experimental genetic deletion of proinflammatory mediators $C X C R 2, C D 24, T N F-\alpha$, and epimorphin significantly reduces intestinal tumor numbers in $A p c^{M i n /+}$ mice. ${ }^{95-98}$

Inflammation might also contribute to some other known risk and protective factors in CRC. For example, high fat diets and obesity predispose humans to $\mathrm{CRC}, A p c^{\mathrm{Min} / \mathrm{t}}$ mice to increased intestinal polyposis, and AOM-treated mice to pre-cancerous colon lesions. ${ }^{99,100}$ Obesity has been associated 
with adipose tissue macrophage malfunction and low-level inflammation. ${ }^{101-103} \mathrm{~A}$ recent report showed increased inflammatory mediators in $A p c^{M i n /+}$ mice on high fat diet relative to $A p c^{\mathrm{Min} / \mathrm{+}}$ mice on regular lab diet. ${ }^{104}$ In addition, many natural products including curcumin, grape antioxidant fibers, and brown rice reduce colon tumors in various mouse models, presumably by reducing inflammation. ${ }^{105-109}$

The mechanisms by which inflammation can enhance colon tumorigenesis are not completely delineated. Inflammation activates many pathways that synergize with Wnt signal activation in CRC tumorigenesis including AKT, KRAS, BRAF, HIF1- $\alpha$, and TGF- $\beta$. DNA damage and epigenetic changes that are associated with inflammation could also contribute to tumor formation. ${ }^{59}$

Many inflammatory pathways converge to activate the prosurvival NF- $\mathrm{KB}$ pathway, ${ }^{59}$ which is also activated in colonic mucosa from IBD patients. ${ }^{110} \mathrm{NF}-\kappa \mathrm{B}$ pathway activation increases proliferation and decreases apoptosis in CRC cell lines and mouse colon mucosa, ${ }^{110,111}$ drugs that inhibit the $\mathrm{NF}-\kappa \mathrm{B}$ pathway decrease intestinal tumorigenesis in $A p c^{\mathrm{Min} /+}$ mice. ${ }^{112}$ Aspirin, an NSAID that decreases intestinal polyposis in both mouse models and FAP patients and protects from $\mathrm{CRC}$, inhibits the $\mathrm{NF}-\kappa \mathrm{B}$ pathway and also increases Apc/APC expression. ${ }^{113}$

Inflammation can increase DNA damage and accelerate mutagenesis. The rate of reactive oxygen species (ROS) production, including nitric oxide (NO), is augmented in inflamed tissues. ROS are genotoxic and increase DNA mutation rates..$^{55,58,114,115}$ Inhibiting NO production reduces intestinal polyp formation in $A p c^{\mathrm{Min} / \mathrm{t}}$ mice as well as inflammatory models of colitis. ${ }^{116,117}$ Notably, activation of the NF- $\kappa B$ pathway by constitutive activation of its upstream activator, IKK $\beta$, enhances intestinal polyposis and elevates DNA damage in $A p c^{580 D / 4}$ mice. ${ }^{118} \mathrm{NO}$ synthase inhibitors reduce this DNA damage and intestinal tumorigenesis, suggesting that accelerating $A p c \mathrm{LOH}$ (loss of heterozygosity) due to the DNA damaging effect of NO is the cause of enhanced tumorigenicity in these mice. ${ }^{118}$ Inflammation may also induce DNA damage by increasing the production of other mutagenic factors including trans-4-hydroxy-2-nonenal from the activated inflammatory cells, which can further induce chromosomal breakage in nearby epithelial cells. ${ }^{119}$ Moreover, chronic inflammation can also reduce DNA mismatch repair proteins. ${ }^{120,121}$

Chronic inflammation is also associated with epigenetic changes including changes in miRNA, DNA hypermethylation, and aberrant methyl histone markings. ${ }^{122}$ Colitis leads to upregulation of miRNA-155 $5^{123}$; miRNA-155 targets $A P C$ and thus, activates $\beta$-catenin. ${ }^{124}$ The protumorigenic effect of chronic colitis has also been linked to prostaglandin (PG) formation through induction of cyclooxygenase-2 (COX-2). ${ }^{125}$ COX-2 is the rate-limiting step in PGE2 formation from arachidonic acid. ${ }^{122}$ Both Cox-2 and PGE2 promote Wnt signaling, increase cellular proliferation, inhibit apoptosis, promote angiogenesis, and enhance metastasis. ${ }^{126-129}$ Conditional deletion of Cox-2 results in significant reduction of intestinal tumors in $A p c^{\mathrm{Min} /+}$ and $A p c^{\Delta 716 /+}$ mice, ${ }^{130,131} \mathrm{Cox}-2$ is also targeted by NSAIDs and selective Cox-2 inhibitors such as Celebrex, both of which reduce intestinal tumorigenesis in patients and mouse models with germ line $A P C /$ Apc mutations. ${ }^{122}$

\section{$A P C$ mutations and inflammation}

In the previous section we presented evidence that inflammation accelerates intestinal tumorigenesis in the presence of $A p c$ mutations. However, there is evidence that $A p c$ mutations can enhance colitis. Proinflammatory mediators Cox-1, Cox-2, MIP-2, OPN, CXCR-2, and Gro- $\alpha$ mRNA are upregulated in colonic polyps in $A p c^{\mathrm{Min} /+}$ mice relative to epithelial cells from normal mice. ${ }^{132}$ Of these genes, only Cox-2 is a defined Wnt target. ${ }^{133,134}$ The other mediators have not been linked to activated Wnt signaling resulting from $A p c$ mutations. In addition, mRNA and serum protein levels of proinflammatory cytokines MCP-1, IL-6, IL-1 $\beta$, and TNF- $\alpha$ increase with the progression of intestinal tumorigenesis and correlate with tumor size. ${ }^{135}$ Moreover, a global expression analysis showed differential expression of inflammatory genes, Lcn 2 and N4wbp4, in Apc ${ }^{\mathrm{Min} / 4}$ polyps. ${ }^{136}$ In another mouse model (CPC-APC), conditional truncation of $A p c$ in the distal part of the small intestine and colon resulted in inflammatory cell infiltration and upregulation of Il-17 and Il-23 in the developing polyps. ${ }^{137}$

Recently, we described a mouse model with a germ line Apc mutation that compromises the ability of Apc to locate to the nucleus. ${ }^{54}$ These $A p c^{m N L S / m N L S}$ mice only rarely develop tumors, and homozygous mutant mice are viable. However, the $A p c^{m N L S}$ allele increases tumor formation when combined with the $A p c^{M i n}$ allele $\left(A p c^{m N L S / M i n}\right.$ mice).$^{54}$ Notably, $A p c^{m N L S / m N L S}$ mice have higher expression of inflammatory mediators Cox-2 and MIP-2 and are more susceptible to DSS-induced colitis and AOM-DSS-induced colon tumorigenesis. ${ }^{138}$ Rats with germ line $A p c$ mutation resulting in truncation of the C-terminal 300 amino acids (KAD rats) do not develop tumors but are also more susceptible to DSS-induced inflammation and AOM-DSS-induced colon tumorigenesis. ${ }^{139}$

$A P C$ mutation can induce colitis by several mechanisms. First, $A P C$ mutations can decrease mucus production and 
therefore reduce the barrier between gut microbes and intestinal tissues. ${ }^{137}$ Apc normally functions in promoting cellular differentiation of intestinal lineages including mucusproducing goblet cells. ${ }^{23,140} A p c^{m N L S / m N L S}$ mice have reduced expression of Hath-1 and fewer goblet cells in their small intestines and less $M u c-2$ mRNA in their colons, relative to their wild-type littermates. ${ }^{54,138}$ Hath-1 is a transcription factor that participates in goblet cell differentiation and is negatively regulated by Wnt signaling. ${ }^{17,141}$ Muc-2 is the major protective mucin in the colon. Muc-2 knockout mice develop colitis and have spontaneous colonic tumors. ${ }^{142,143}$ Muc-2 mutation also enhances intestinal tumorigenesis in $A p c^{\text {Min/+ }}$ mice. ${ }^{143,144}$ Furthermore, induction of inflammation in $A p c^{m N L S / m N L S}$ mice using DSS results in significantly fewer goblet cells and reduced $M u c-2$ mRNA, relative to DSS-treated wild-type mice. ${ }^{138}$ Goblet cell differentiation requires low Notch signal and treating $A p c^{\mathrm{Min} /+}$ mice with a $\gamma$-secretase inhibitor, inhibited Notch signaling and increased goblet cell differentiation in intestinal tumors. ${ }^{145} \mathrm{~A}$ potential link between Notch signaling and APC is that APC is in a double negative feedback loop with the transcription inhibitor Msi-1 ${ }^{146}$ Msi-1 activates Notch signaling by inhibiting the Notch repressor, Numb. ${ }^{147}$ In cases of Apc mutation, Msi-1 is upregulated; activating Notch signaling. ${ }^{23,148}$ However, a direct role of Msi-1 in goblet cell differentiation has not been examined. Finally, FAP patients and CPC-APC mice with conditional truncation of APC/Apc showed reduced mucus production of polyps, which displayed Apc LOH. ${ }^{137}$ Colonic mucosa in AOM-treated rats as well as FAP patients shows foci with depleted mucin. ${ }^{149,150}$ These mucin-depleted foci are correlated with tumor number and have high rates of $A p c$ mutations. ${ }^{151} A p c$-mutant (PIRC) rats also show mucin-depleted foci that increase in number as the rats age. ${ }^{152}$ Notably, the NSAID sulindac, reduces the number of polyps as well as mucin-depleted foci in PIRC rats. ${ }^{152}$ Collectively, these data suggest that Apc mutations predispose to the precancerous mucin-depleted foci.

Alteration of $A p c$ can also affect other intestinal epithelial barrier activities. APC loss effects localization of tight junction protein ZO- $1 .{ }^{153}$ Loss of APC and upregulated Wnt signaling are also associated with increased expression of tight junction protein claudin-1 in CRCs. ${ }^{154}$ Further, inducible Apc truncation in CPC-APC mice leads to reduced junctional claudin-3, -4, -5, and -7 and decreased levels of JAM-C (junctional adhesion molecule-C) mRNA. ${ }^{137}$ The C-terminus of Apc binds to the junctional protein DLG (Figure 1). In KAD rats, Dlg5 fails to localize to the junction in endothelial cells, resulting in delayed healing after DSS-induced inflam- mation. ${ }^{155}$ Finally, APC interacts with cytoskeletal proteins including those of microtubules and intermediate filaments, which are important in formation and maintenance of tight junctions. ${ }^{31,156,157}$ Apc mutations alter cytoskeletal organization in intestinal epithelial cells and affect cell polarity. ${ }^{158}$ Whether these changes in epithelial organization enhance colitis is not clear.

Apc mutations might also induce inflammation by activating Wnt signaling. Cox-2 and $i N O S$ are Wnt targets. ${ }^{134,159}$ Cox-2 is the rate-limiting enzyme in PGE2 synthesis. PGE2 is involved in processes that lead to inflammation, including, vasodilation, increasing vascular permeability, and chemoattraction of inflammatory cells..$^{59}$

\section{APC, colitis, and microbiome in CRC}

The role of intestinal flora in health and disease is getting increasing attention of late. ${ }^{160,161}$ The development of tools such as deep sequencing has allowed rapid analysis of different intestinal bacteria. The gastrointestinal tract in general and especially the distal portion is home to a large number of microorganisms. The relationship between these florae and the host is mostly symbiotic. ${ }^{160,161}$ The host provides a niche and nutrients, while intestinal florae provide essential vitamins and are crucial for the development of the host immune system. Particular intestinal florae also prevent overgrowth of pathogenic microorganisms by competing with them for limited resources. However, changes in the number, type, or the relative abundance of different intestinal microorganisms (dysbiosis) have been related to many pathological conditions including IBD and CRC. ${ }^{160,162}$ The challenging task for the intestinal epithelial barrier is to regulate the intestinal microbiome by allowing the growth of beneficial species and preventing the growth and invasion of pathogenic and opportunistic organisms.

Disruption of the intestinal epithelial barrier is a hallmark of IBD. ${ }^{163}$ However, the relationship between the epithelial barrier, intestinal florae, and inflammation has multiple levels of complexity. Mucus secretion is stimulated by bacterial colonization. ${ }^{164}$ Germ-free mice have a thin mucus layer, which can be restored to normal thickness by bacterial products including peptidoglycans and lipopolysaccharides. ${ }^{164,165}$ Bacterial products including butyrate and short chain fatty acids also can induce $M u c 2$ transcription via c-Fos/c-Jun and by epigenetic histone alterations. ${ }^{166-169}$ On the other hand, microbes or their metabolic products may induce inflammatory reactions in the colon. Some intestinal florae such as Fusobacteria and Surpulina are enriched in the mucus layer covering regions of enteric inflammation, ${ }^{170,171}$ consistent 
with their ability to dissolve the mucus layer and thus provide access to other microbes. ${ }^{172}$ Clostridia-like gram-positive segmented filamentous bacteria induce intestinal inflammation which predisposes to colitis but also protects mice from some enteric infections. ${ }^{173}$ In contrast, some bacterial products such as short chain fatty acids and butyrate inhibit colitis by stimulating epithelial cells to secrete the anti-inflammatory cytokines IL-10 and IL-18. ${ }^{174-176}$

Several mechanisms linking the colonic microbiome to $\mathrm{CRC}$ have been proposed. In human patients, the florae of colonic adenomas and adenocarcinomas are enriched with fusobacterial species relative to normal colon tissue. ${ }^{177,178}$ Fusobacteria enhance intestinal tumorigenesis in $A p c^{\mathrm{Min} /+}$ mice resulting in a proinflammatory gene expression signature in the tumor cells. ${ }^{177}$ Reducing microbial-induced inflammation by deleting the PAMP pathway adaptor protein Myd88 decreases intestinal tumors in $A p c^{\mathrm{Min} /+}$ mice and colon tumors in AOM-treated mice. ${ }^{179,180}$ Furthermore, transplantation of bone marrow from mice with mutations in genes encoding PAMP adaptor proteins Myd88, Tlr2, 4, and 9 reduces inflammation and tumor load in $\mathrm{CPC}-\mathrm{APC}$ mice. ${ }^{137}$ Finally, deletion of anti-inflammatory cytokine $I l-10$ alters the intestinal microbiota and increases the intestinal tumor number in $A p c^{4468}$ mice; treating these mice with broad-spectrum antibiotics decreased the overall microbial diversity and also decreased the intestinal tumor multiplicity. ${ }^{181}$

Microorganisms can also secrete carcinogenic metabolites that can mutate DNA. In addition to ROS produced by inflammatory cells as the result of bacterial-induced inflammation, some colonic bacteria including the gram-positive Enterococcus faecalis produce hydroxyl radicals. ${ }^{182-184}$ Still, other colon-inhabitant gram-negative, Escherichia coli, produce a toxin that can cause DNA damage and CRC. ${ }^{185}$ Bacteria may also secrete chemicals that directly induce proliferation. For example, the exotoxin fragilysin secreted by some Bacteroid species induces c-Myc which stimulates cellular proliferation. ${ }^{186}$ Bacterial metabolites such as $\mathrm{H}_{2} \mathrm{~S}$ are produced by many Enterobacterial species commonly found in the normal colon. ${ }^{187} \mathrm{H}_{2} \mathrm{~S}$ can activate the RAS-MEK pathway and induce cellular proliferation in mice. ${ }^{188}$

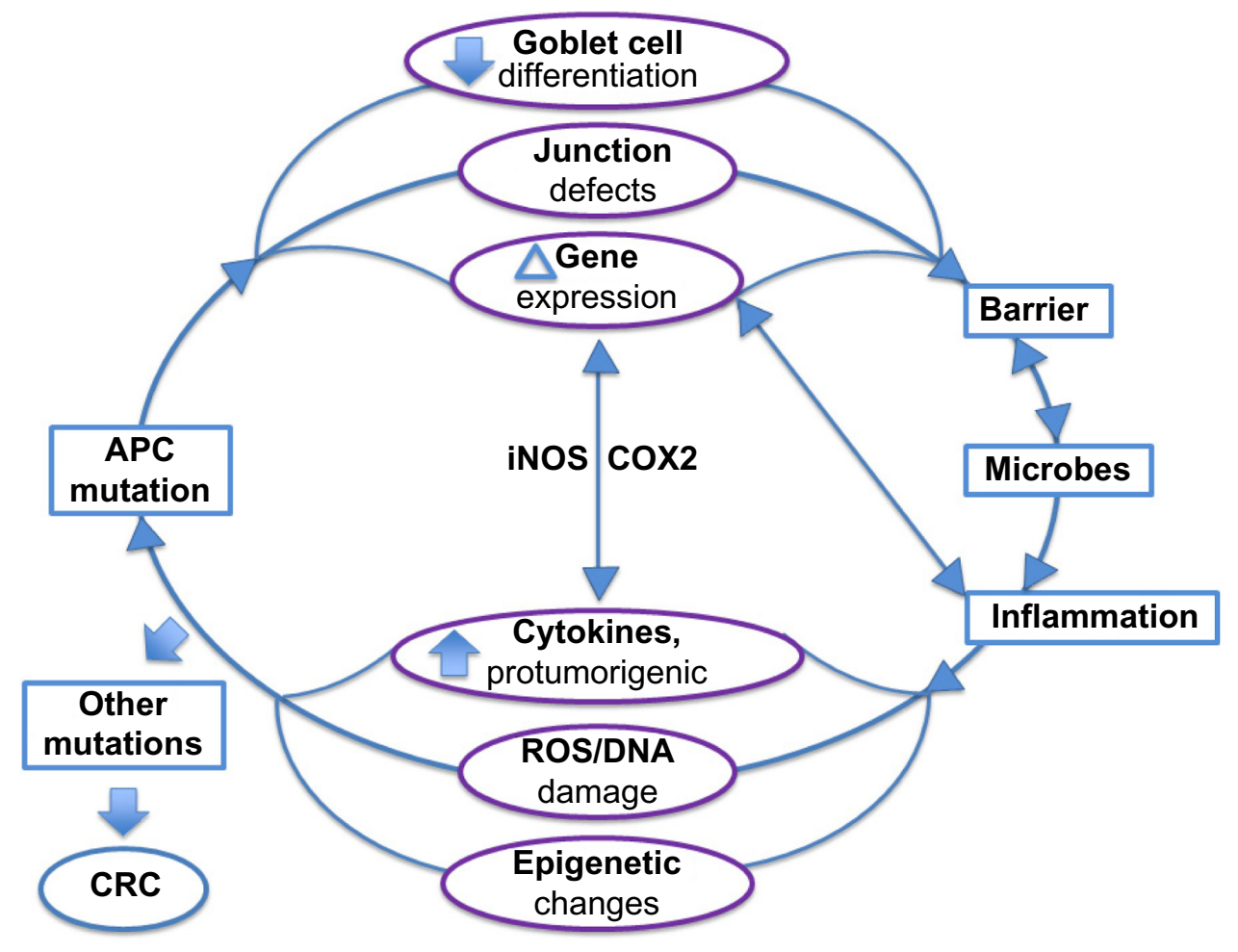

Figure 3 Potential roles for APC in inflammation.

Notes: APC normally promotes differentiation of goblet cells which generate and secrete mucus. Protective mucus layers provide a physical barrier between luminal microbes and the epithelial cells lining the intestine. APC interacts with various junctional proteins, further contributing to a barrier between the luminal contents and the immune cells of the stroma. APC regulates expression of genes, some of which are involved in inflammation. Microbial breach of the intestinal barrier results in inflammation. Consequences of inflammation include DNA damage and epigenetic changes that can result in additional mutation of tumor suppressor genes and oncogenes that further promote colorectal carcinogenesis.

Abbreviations: APC, adenomatous polyposis coli; iNOS, induced nitric oxide synthase; CRC, colorectal cancer; ROS, reactive oxygen species; COX-2, cyclooxygenase-2. 
Several observations made in mouse models point to an interaction between genetic lesions, intestinal florae and CRC. Smad3-deficient mice develop colon tumors only in the presence of helicobacter infection. ${ }^{189} \mathrm{~Tb} \times 2$ and $\mathrm{Rag} 2^{-/-}$ulcerative colitis (TRUC) mice develop colitis and colitis-associated colon cancer, but not when raised in a germ-free environment. ${ }^{190}$ Similarly, $I l 10^{-/-}$mice develop colitis-associated colon tumors only if they have intestinal bacteria. ${ }^{191}$ NLRP6 is a component of the innate immune response that senses microbes, and NLRP6 deletion in intestinal epithelial cells induces colitis and colitis-associated tumorigenesis. ${ }^{192}$ These NLRP6-deficient mice also have changes in the bacterial flora composition with more abundant Bacteroids in the colon. Remarkably, cohousing these NLRP6-mutant mice with wildtype mice results in development of colitis and colon tumors in the wild-type mice, consistent with transmissible tumor promoter. ${ }^{192,193}$ A similar transmissible, tumor-promoter has been described in mice with mutations in other components of the innate immune response, NOD2 and RIP2. ${ }^{194}$ Furthermore, expression of the secreted anti-inflammation mediator/antimicrobial, Pla2g2a in intestinal epithelial cells reduces the incidence of intestinal polyps in $\mathrm{Ap} \mathrm{C}^{\mathrm{Min} / \mathrm{t}}$ mice and in orthotopic xenografts of human colon cancer cells. ${ }^{195,196}$ Notably, exogenous expression of the Pla2g2a gene prevents colon tumorigenesis in Muc2-deficient mice. ${ }^{197}$

Although connections are starting to emerge, the precise relationship between the tumor suppressor Apc and intestinal flora is not well defined. $A p c^{M i n /+}$ mice raised in a germ-free environment develop fewer polyps than $A p c^{\mathrm{Min} / \mathrm{t}}$ mice housed in standard conditions. ${ }^{198}$ However, this tumor reduction is statistically significant only in the middle portion of the small intestine, with no reduction in the number of tumors in the colon. ${ }^{198}$ This region specificity may represent a varied role for different microbial species in discrete regions of the gastrointestinal tract. On the other hand, $A p c^{\Delta 14 / 4}$ mice developed more polyps when raised in germ-free conditions than in standard housing conditions. ${ }^{199}$ Together, these data suggest an allele-specific interaction of $A p c$ with the microbial content of the gut. Notably, mutations in $A p c^{\mathrm{Min} /+}$ and $A p c^{\Delta 14 /+}$ are expected to result in truncated Apc proteins that differ by 403 amino acids. ${ }^{5}$ The contrasting effect of germ-free conditions on polyp number in $A p c^{M i n /+}$ and $A p c^{\Delta l 4 /+}$ could also represent other contributing factors that vary between the two experimental conditions including other genetic loci and diet. ${ }^{4}$

\section{Conclusion}

The results gathered from studies of rodent CRC models reveal a complex interplay of genetics, inflammation, and the microbiome that gives rise to a cancer phenotype. APC is a major tumor suppressor in the colon. Although the most universally appreciated APC role is that of Wnt signal antagonist, APC is multifaceted. In this review, we describe an emerging role for APC in colitis. We propose that this APC role as regulator of the inflammatory response might be particularly critical in the colon and thus contribute to the high frequency of $A P C$ mutations seen in CRC compared to cancers of other tissues (Figure 3). Unearthing the precise role for APC in suppression of inflammation will expand the repertoire of therapeutic strategies aimed at rescuing the functions of this multifaceted and fascinating tumor suppressor protein.

\section{Acknowledgments}

The authors recognize grants P30CA168524 and P20 RR016475 for financial support.

\section{Disclosure}

The authors report no conflicts of interest in this work.

\section{References}

1. American Cancer Society. Cancer Facts and Figures 2014. Atlanta, GA: American Cancer Society; 2014.

2. Kinzler KW, Vogelstein B. Lessons from hereditary colorectal cancer. Cell. 1996;87(2):159-170.

3. Singh S, Singh PP, Murad MH, Singh H, Samadder NJ. Prevalence, risk factors, and outcomes of interval colorectal cancers: a systematic review and meta-analysis. Am J Gastroenterol. 2014;109(9):1375-1389.

4. Zeineldin M, Neufeld KL. Understanding phenotypic variation in rodent models with germline apc mutations. Cancer Res. 2013;73(8): 2389-2399.

5. Zeineldin M, Neufeld KL. More than two decades of Apc modeling in rodents. Biochim Biophys Acta. 2013;1836(1):80-89.

6. Powell SM, Zilz N, Beazer-Barclay Y, et al. APC mutations occur early during colorectal tumorigenesis. Nature. 1992;359(6392):235-237.

7. Kinzler KW, Nilbert MC, Su LK, et al. Identification of FAP locus genes from chromosome 5q21. Science. 1991;253(5020):661-665.

8. Groden J, Thliveris A, Samowitz W, et al. Identification and characterization of the familial adenomatous polyposis coli gene. Cell. 1991; 66(3):589-600.

9. Nieuwenhuis MH, Vasen HF. Correlations between mutation site in APC and phenotype of familial adenomatous polyposis (FAP): a review of the literature. Crit Rev Oncol Hematol. 2007;61(2):153-161.

10. Senda T, Iizuka-Kogo A, Onouchi T, Shimomura A. Adenomatous polyposis coli (APC) plays multiple roles in the intestinal and colorectal epithelia. Med Mol Morphol. 2007;40(2):68-81.

11. Phelps RA, Broadbent TJ, Stafforini DM, Jones DA. New perspectives on APC control of cell fate and proliferation in colorectal cancer. Cell Cycle. 2009;8(16):2549-2556.

12. Polakis P. Wnt signaling and cancer. Genes Dev. 2000;14(15): 1837-1851.

13. Klaus A, Birchmeier W. Wnt signalling and its impact on development and cancer. Nat Rev Cancer. 2008;8(5):387-398.

14. He TC, Sparks AB, Rago C, et al. Identification of c-MYC as a target of the APC pathway. Science. 1998;281(5382):1509-1512.

15. Tetsu O, McCormick F. Beta-catenin regulates expression of cyclin D1 in colon carcinoma cells. Nature. 1999;398(6726):422-426. 
16. Yan D, Wiesmann M, Rohan M, et al. Elevated expression of axin2 and hnkd mRNA provides evidence that Wnt/beta-catenin signaling is activated in human colon tumors. Proc Natl Acad Sci USA. 2001;98(26): 14973-14978.

17. Leow CC, Romero MS, Ross S, Polakis P, Gao WQ. Hath1, downregulated in colon adenocarcinomas, inhibits proliferation and tumorigenesis of colon cancer cells. Cancer Res. 2004;64(17):6050-6057.

18. Sancho E, Batlle E, Clevers H. Signaling pathways in intestinal development and cancer. Annu Rev Cell Dev Biol. 2004;20:695-723.

19. Barker N. Adult intestinal stem cells: critical drivers of epithelial homeostasis and regeneration. Nat Rev Mol Cell Biol. 2014;15(1):19-33.

20. Cadigan KM, Nusse R. Wnt signaling: a common theme in animal development. Genes Dev. 1997;11(24):3286-3305.

21. Ricci-Vitiani L, Fabrizi E, Palio E, De Maria R. Colon cancer stem cells. J Mol Med. 2009;87(11):1097-1104.

22. Barker N, Clevers H. Tracking down the stem cells of the intestine: strategies to identify adult stem cells. Gastroenterology. 2007;133(6): 1755-1760.

23. Sansom OJ, Reed KR, Hayes AJ, et al. Loss of Apc in vivo immediately perturbs Wnt signaling, differentiation, and migration. Genes Dev. 2004;18(12):1385-1390.

24. Fodde R, Kuipers J, Rosenberg C, et al. Mutations in the APC tumour suppressor gene cause chromosomal instability. Nat Cell Biol. 2001;3(4):433-438.

25. Rubinfeld B, Souza B, Albert I, et al. Association of the APC gene product with beta-catenin. Science. 1993;262(5140):1731-1734.

26. Su LK, Vogelstein B, Kinzler KW. Association of the APC tumor suppressor protein with catenins. Science. 1993;262(5140):1734-1737.

27. Nathke IS, Adams CL, Polakis P, Sellin JH, Nelson J. The adenomatous polyposis coli tumor suppressor protein localizes to plasma membrane sites involved in active cell migration. J. Cell Biol. 1996;134:165-179.

28. Deka J, Kuhlmann J, Muller O. A domain within the tumor suppressor protein APC shows very similar biochemical properties as the microtubule-associated protein tau. Eur J Biochem. 1998;253(3): 591-597.

29. Su LK, Burrell M, Hill DE, et al. APC binds to the novel protein EB1. Cancer Res. 1995;55(14):2972-2977.

30. Askham JM, Moncur P, Markham AF, Morrison EE. Regulation and function of the interaction between the APC tumour suppressor protein and EB1. Oncogene. 2000;19(15):1950-1958.

31. Wang Y, Azuma Y, Friedman DB, Coffey RJ, Neufeld KL. Novel association of APC with intermediate filaments identified using a new versatile APC antibody. BMC Cell Biol. 2009;10:75.

32. Green RA, Kaplan KB. Chromosome instability in colorectal tumor cells is associated with defects in microtubule plus-end attachments caused by a dominant mutation in APC. J Cell Biol. 2003;163(5): 949-961.

33. Radulescu S, Ridgway RA, Appleton P, et al. Defining the role of APC in the mitotic spindle checkpoint in vivo: APC-deficient cells are resistant to Taxol. Oncogene. 2010;29(49):6418-6427.

34. Anderson CB, Neufeld KL, White RL. Subcellular distribution of Wnt pathway proteins in normal and neoplastic colon. Proc Natl Acad Sci U S A. 2002;99(13):8683-8688.

35. Henderson BR. Nuclear-cytoplasmic shuttling of APC regulates beta-catenin subcellular localization and turnover. Nat Cell Biol. 2000;2(9):653-660.

36. Neufeld KL. Nuclear APC. Adv Exp Med Biol. 2009;656:13-29.

37. Zhang F, White RL, Neufeld KL. Phosphorylation near nuclear localization signal regulates nuclear import of adenomatous polyposis coli protein. Proc Natl Acad Sci U S A. 2000;97(23):12577-12582.

38. Neufeld KL, Zhang F, Cullen BR, White RL. APC-mediated downregulation of beta-catenin activity involves nuclear sequestration and nuclear export. EMBO Rep. 2000;1(6):519-523.

39. Wang Y, Azuma Y, Moore D, Osheroff N, Neufeld KL. Interaction between tumor suppressor adenomatous polyposis coli and topoisomerase II \{alpha\}: implication for the G2/M transition. Mol Biol Cell. 2008;19(10):4076-4085.
40. Wang Y, Coffey RJ, Osheroff N, Neufeld KL. Topoisomerase IIalpha binding domains of adenomatous polyposis coli influence cell cycle progression and aneuploidy. PLoS One. 2010;5(4):e9994.

41. Jaiswal AS, Balusu R, Armas ML, Kundu CN, Narayan S. Mechanism of adenomatous polyposis coli (APC)-mediated blockage of long-patch base excision repair. Biochemistry. 2006;45(51):15903-15914.

42. Jaiswal AS, Banerjee S, Aneja R, Sarkar FH, Ostrov DA, Narayan S. DNA polymerase beta as a novel target for chemotherapeutic intervention of colorectal cancer. PLoS One. 2011;6(2):e16691.

43. Jaiswal AS, Narayan S. A novel function of adenomatous polyposis coli (APC) in regulating DNA repair. Cancer Lett. 2008;271(2): $272-280$.

44. Jaiswal AS, Narayan S. Assembly of the base excision repair complex on abasic DNA and role of adenomatous polyposis coli on its functional activity. Biochemistry. 2011;50(11):1901-1909.

45. Narayan S, Jaiswal AS, Balusu R. Tumor suppressor APC blocks DNA polymerase beta-dependent strand displacement synthesis during long patch but not short patch base excision repair and increases sensitivity to methylmethane sulfonate. J Biol Chem. 2005;280(8): 6942-6949.

46. Larabee JL, Shakir SM, Hightower L, Ballard JD. Adenomatous polyposis coli protein associates with $\mathrm{C} / \mathrm{EBP}$ beta and increases Bacillus anthracis edema toxin stimulated gene expression in macrophages. J Biol Chem. 2011;286(22):19364-19372.

47. Deka J, Herter P, Sprenger-Haussels M, et al. The APC protein binds to A/T rich DNA sequences. Oncogene. 1999;18(41):5654-5661.

48. Kohler EM, Derungs A, Daum G, Behrens J, Schneikert J. Functional definition of the mutation cluster region of adenomatous polyposis coli in colorectal tumours. Hum Mol Genet. 2008;17(13):1978-1987.

49. Gaspar C, Cardoso J, Franken P, et al. Cross-species comparison of human and mouse intestinal polyps reveals conserved mechanisms in adenomatous polyposis coli (APC)-driven tumorigenesis. Am J Pathol. 2008;172(5):1363-1380.

50. Amos-Landgraf JM, Kwong LN, Kendziorski CM, et al. A target-selected Apc-mutant rat kindred enhances the modeling of familial human colon cancer. Proc Natl Acad Sci U S A. 2007;104(10):4036-4041.

51. Moser AR, Pitot HC, Dove WF. A dominant mutation that predisposes to multiple intestinal neoplasia in the mouse. Science. 1990;247(4940): 322-324.

52. Yokoyama A, Nomura R, Kurosumi M, et al. The C-terminal domain of the adenomatous polyposis coli (Apc) protein is involved in thyroid morphogenesis and function. Med Mol Morphol. 2011;44(4):207-212.

53. Lewis A, Davis H, Deheragoda M, et al. The C-terminus of Apc does not influence intestinal adenoma development or progression. J Pathol. 2012;226(1):73-83.

54. Zeineldin M, Cunningham J, McGuinness W, et al. A knock-in mouse model reveals roles for nuclear Apc in cell proliferation, Wnt signal inhibition and tumor suppression. Oncogene. 2012;31(19):2423-2437.

55. Rizzo A, Pallone F, Monteleone G, Fantini MC. Intestinal inflammation and colorectal cancer: a double-edged sword? World J Gastroenterol. 2011;17(26):3092-3100.

56. Rowland KJ, Choi PM, Warner BW. The role of growth factors in intestinal regeneration and repair in necrotizing enterocolitis. Semin Pediatr Surg. 2013;22(2):101-111.

57. Borrello MG, Degl'Innocenti D, Pierotti MA. Inflammation and cancer: the oncogene-driven connection. Cancer Lett. 2008;267(2):262-270.

58. Rakoff-Nahoum S. Why cancer and inflammation? Yale J Biol Med. 2006;79(3-4):123-130.

59. Terzic J, Grivennikov S, Karin E, Karin M. Inflammation and colon cancer. Gastroenterology. 2010;138(6):2101-2114.

60. Okayasu I, Hatakeyama S, Yamada M, Ohkusa T, Inagaki Y, Nakaya R. A novel method in the induction of reliable experimental acute and chronic ulcerative colitis in mice. Gastroenterology. 1990;98(3):694-702.

61. Clapper ML, Cooper HS, Chang WC. Dextran sulfate sodiuminduced colitis-associated neoplasia: a promising model for the development of chemopreventive interventions. Acta Pharmacol Sin. 2007;28(9):1450-1459. 
62. Hirono I, Kuhara K, Hosaka S, Tomizawa S, Golberg L. Induction of intestinal tumors in rats by dextran sulfate sodium. J Natl Cancer Inst. 1981;66(3):579-583.

63. Ohkusa T. [Production of experimental ulcerative colitis in hamsters by dextran sulfate sodium and changes in intestinal microflora]. Nihon Shokakibyo Gakkai zasshi. 1985;82(5):1327-1336. Japanese.

64. Tanaka T, Kohno H, Suzuki R, Yamada Y, Sugie S, Mori H. A novel inflammation-related mouse colon carcinogenesis model induced by azoxymethane and dextran sodium sulfate. Cancer Sci. 2003;94(11): 965-973.

65. Cooper HS, Murthy SN, Shah RS, Sedergran DJ. Clinicopathologic study of dextran sulfate sodium experimental murine colitis. Lab Invest. 1993;69(2):238-249.

66. Cooper HS, Murthy S, Kido K, Yoshitake H, Flanigan A. Dysplasia and cancer in the dextran sulfate sodium mouse colitis model. Relevance to colitis-associated neoplasia in the human: a study of histopathology, B-catenin and p53 expression and the role of inflammation. Carcinogenesis. 2000;21(4):757-768.

67. Aust DE, Terdiman JP, Willenbucher RF, et al. The APC/beta-catenin pathway in ulcerative colitis-related colorectal carcinomas: a mutational analysis. Cancer. 2002;94(5):1421-1427.

68. Takahashi M, Wakabayashi K. Gene mutations and altered gene expression in azoxymethane-induced colon carcinogenesis in rodents. Cancer Sci. 2004;95(6):475-480.

69. De Filippo C, Caderni G, Bazzicalupo M, et al. Mutations of the Apc gene in experimental colorectal carcinogenesis induced by azoxymethane in F344 rats. Br J Cancer. 1998;77(12):2148-2151.

70. Camilleri M, Madsen K, Spiller R, Van Meerveld BG, Verne GN Intestinal barrier function in health and gastrointestinal disease. Neurogastroent Motil. 2012;24(10):976-976.

71. Voreades N, Kozil A, Weir TL. Diet and the development of the human intestinal microbiome. Front Microbiol. 2014;5:494

72. Nuding S, Antoni L, Stange EF. The host and the flora. Dig Dis. 2013;31(3-4):286-292.

73. Serban DE. Gastrointestinal cancers: influence of gut microbiota, probiotics and prebiotics. Cancer Lett. 2014;345(2):258-270.

74. Dorofeyev AE, Vasilenko IV, Rassokhina OA, Kondratiuk RB. Mucosal barrier in ulcerative colitis and Crohn's disease. Gastroenterol Res Pract. 2013;2013:431231.

75. Johansson ME, Hansson GC. Mucus and the goblet cell. Dig Dis. 2013;31(3-4):305-309.

76. Liang GH, Weber CR. Molecular aspects of tight junction barrier function. Curr Opin Pharmacol. 2014;19C:84-89.

77. Gunther C, Buchen B, Neurath MF, Becker C. Regulation and pathophysiological role of epithelial turnover in the gut. Semin Cell Dev Biol. 2014;35C:40-50.

78. Raybould HE. Gut microbiota, epithelial function and derangements in obesity. J Physiol. 2012;590(Pt 3):441-446.

79. Gkouskou KK, Deligianni C, Tsatsanis C, Eliopoulos AG. The gut microbiota in mouse models of inflammatory bowel disease. Front Cell Infect Microbiol. 2014;4:28.

80. Kern SE, Redston M, Seymour AB, et al. Molecular genetic profiles of colitis-associated neoplasms. Gastroenterology. 1994;107(2):420-428.

81. Fogt F, Vortmeyer AO, Goldman H, Giordano TJ, Merino MJ, Zhuang $Z$. Comparison of genetic alterations in colonic adenoma and ulcerative colitis-associated dysplasia and carcinoma. Hum Pathol. 1998;29(2):131-136.

82. Fearon ER, Vogelstein B. A genetic model for colorectal tumorigenesis. Cell. 1990;61(5):759-767.

83. Cooper HS, Everley L, Chang WC, et al. The role of mutant Apc in the development of dysplasia and cancer in the mouse model of dextran sulfate sodium-induced colitis. Gastroenterology. 2001;121(6): 1407-1416.

84. Luongo C, Moser AR, Gledhill S, Dove WF. Loss of Apc+ in intestinal adenomas from Min mice. Cancer Res. 1994;54(22):5947-5952.

85. Huang EH, Park JC, Appelman H, et al. Induction of inflammatory bowel disease accelerates adenoma formation in Min \pm mice. Surgery. 2006;139(6):782-788.
86. Xiao H, Yin W, Khan MA, et al. Loss of single immunoglobulin interlukin-1 receptor-related molecule leads to enhanced colonic polyposis in Apc(min) mice. Gastroenterology. 2010;139(2): 574-585.

87. Asfaha S, Dubeykovskiy AN, Tomita H, et al. Mice that express human interleukin- 8 have increased mobilization of immature myeloid cells, which exacerbates inflammation and accelerates colon carcinogenesis. Gastroenterology. 2013;144(1):155-166.

88. Cheung KL, Lee JH, Khor TO, et al. Nrf2 knockout enhances intestinal tumorigenesis in $\mathrm{Apc}(\mathrm{min} /+)$ mice due to attenuation of anti-oxidative stress pathway while potentiates inflammation. Mol Carcinog. 2014; 53(1):77-84.

89. Khor TO, Huang MT, Prawan A, et al. Increased susceptibility of Nrf2 knockout mice to colitis-associated colorectal cancer. Cancer Prev Res (Phila). 2008;1(3):187-191.

90. Quesada CF, Kimata H, Mori M, Nishimura M, Tsuneyoshi T, Baba S. Piroxicam and acarbose as chemopreventive agents for spontaneous intestinal adenomas in APC gene 1309 knockout mice. Jpn J Cancer Res. 1998;89(4):392-396.

91. Sasai H, Masaki M, Wakitani K. Suppression of polypogenesis in a new mouse strain with a truncated Apc(Delta474) by a novel COX-2 inhibitor, JTE-522. Carcinogenesis. 2000;21(5):953-958.

92. Ishikawa H, Wakabayashi K, Suzuki S, et al. Preventive effects of low-dose aspirin on colorectal adenoma growth in patients with familial adenomatous polyposis: double-blind, randomized clinical trial. Cancer Med. 2013;2(1):50-56.

93. Barnes CJ, Lee M. Chemoprevention of spontaneous intestinal adenomas in the adenomatous polyposis coli Min mouse model with aspirin. Gastroenterology. 1998;114(5):873-877.

94. Guillen-Ahlers H, Buechler SA, Suckow MA, Castellino FJ, Ploplis VA. Sulindac treatment alters collagen and matrilysin expression in adenomas of ApcMin/+ mice. Carcinogenesis. 2008;29(7): 1421-1427.

95. Swietlicki EA, Bala S, Lu J, et al. Epimorphin deletion inhibits polyposis in the Apcmin/+ mouse model of colon carcinogenesis via decreased myofibroblast HGF secretion. Am J Physiol Gastrointest Liver Physiol. 2013;305(8):G564-G572.

96. Lee YS, Choi D, Kim NY, et al. CXCR2 inhibition enhances sulindacmediated suppression of colon cancer development. Int J Cancer. 2014;135(1):232-237.

97. Naumov I, Zilberberg A, Shapira S, et al. CD24 knockout prevents colorectal cancer in chemically induced colon carcinogenesis and in APC(Min)/CD24 double knockout transgenic mice. Int J Cancer. 2014;135(5):1048-1059.

98. Sakai H, Yamada Y, Shimizu M, Saito K, Moriwaki H, Hara A. Genetic ablation of Tnfalpha demonstrates no detectable suppressive effect on inflammation-related mouse colon tumorigenesis. Chem Biol Interact. 2010;184(3):423-430.

99. Baltgalvis KA, Berger FG, Pena MM, Davis JM, Carson JA. The interaction of a high-fat diet and regular moderate intensity exercise on intestinal polyp development in Apc Min/+ mice. Cancer Prev Res (Phila). 2009;2(7):641-649.

100. Padidar S, Farquharson AJ, Williams LM, Kearney R, Arthur JR, Drew JE. High-fat diet alters gene expression in the liver and colon: links to increased development of aberrant crypt foci. Dig Dis Sci. 2012;57(7):1866-1874.

101. van Kruijsdijk RC, van der Wall E, Visseren FL. Obesity and cancer: the role of dysfunctional adipose tissue. Cancer Epidemiol Biomarkers Prev. 2009;18(10):2569-2578.

102. Prieto-Hontoria PL, Perez-Matute P, Fernandez-Galilea M, Bustos M, Martinez JA, Moreno-Aliaga MJ. Role of obesity-associated dysfunctional adipose tissue in cancer: a molecular nutrition approach. Biochim Biophys Acta. 2011;1807(6):664-678.

103. Newmark HL, Lipkin M, Maheshwari N. Colonic hyperplasia and hyperproliferation induced by a nutritional stress diet with four components of Western-style diet. J Natl Cancer Inst. 1990;82(6): 491-496. 
104. Day SD, Enos RT, McClellan JL, Steiner JL, Velazquez KT, Murphy EA. Linking inflammation to tumorigenesis in a mouse model of high-fatdiet-enhanced colon cancer. Cytokine. 2013;64(1):454-462.

105. Villegas I, Sanchez-Fidalgo S, de la Lastra CA. Chemopreventive effect of dietary curcumin on inflammation-induced colorectal carcinogenesis in mice. Mol Nutr Food Res. 2011;55(2):259-267.

106. Ng SC, Lam YT, Tsoi KK, Chan FK, Sung JJ, Wu JC. Systematic review: the efficacy of herbal therapy in inflammatory bowel disease. Aliment Pharmacol Ther. 2013;38(8):854-863.

107. Cheah KY, Bastian SE, Acott TM, Abimosleh SM, Lymn KA, Howarth GS. Grape seed extract reduces the severity of selected disease markers in the proximal colon of dextran sulphate sodium-induced colitis in rats. Dig Dis Sci. 2013;58(4):970-977.

108. Phutthaphadoong S, Yamada Y, Hirata A, et al. Chemopreventive effect of fermented brown rice and rice bran (FBRA) on the inflammationrelated colorectal carcinogenesis in ApcMin/+ mice. Oncol Rep. 2010;23(1):53-59.

109. Sanchez-Tena S, Lizarraga D, Miranda A, et al. Grape antioxidant dietary fiber inhibits intestinal polyposis in ApcMin/+ mice: relation to cell cycle and immune response. Carcinogenesis. 2013;34(8): 1881-1888.

110. Kojima M, Morisaki T, Sasaki N, et al. Increased nuclear factor-kB activation in human colorectal carcinoma and its correlation with tumor progression. Anticancer Res. 2004;24(2B):675-681.

111. Umar S, Sarkar S, Wang Y, Singh P. Functional cross-talk between beta-catenin and NFkappaB signaling pathways in colonic crypts of mice in response to progastrin. J Biol Chem. 2009;284(33): 22274-22284.

112. Wang R, Wang Y, Gao Z, Qu X. The comparative study of acetyl11-keto-beta-boswellic acid (AKBA) and aspirin in the prevention of intestinal adenomatous polyposis in APC(Min/+) mice. Drug Dis Ther. 2014;8(1):25-32.

113. Ashida N, Kishihata M, Tien DN, Kamei K, Kimura T, Yokode M. Aspirin augments the expression of Adenomatous Polyposis Coli protein by suppression of IKKbeta. Biochem Biophys Res Commun. 2014;446(2):460-464.

114. Meira LB, Bugni JM, Green SL, et al. DNA damage induced by chronic inflammation contributes to colon carcinogenesis in mice. JClin Invest. 2008;118(7):2516-2525.

115. Westbrook AM, Wei B, Braun J, Schiestl RH. Intestinal mucosal inflammation leads to systemic genotoxicity in mice. Cancer Res. 2009;69(11):4827-4834.

116. Scott DJ, Hull MA, Cartwright EJ, et al. Lack of inducible nitric oxide synthase promotes intestinal tumorigenesis in the Apc(Min/+) mouse. Gastroenterology. 2001;121(4):889-899.

117. Kohno H, Takahashi M, Yasui Y, et al. A specific inducible nitric oxide synthase inhibitor, ONO-1714 attenuates inflammation-related large bowel carcinogenesis in male Apc(Min/+) mice. Int J Cancer. 2007;121(3):506-513.

118. Shaked H, Hofseth LJ, Chumanevich A, et al. Chronic epithelial NF-kappaB activation accelerates APC loss and intestinal tumor initiation through iNOS up-regulation. Proc Natl Acad Sci U S A. 2012;109(35):14007-14012.

119. Yang Y, Wang X, Huycke T, Moore DR, Lightfoot SA, Huycke MM. Colon macrophages polarized by commensal bacteria cause colitis and cancer through the bystander effect. Transl Oncol. 2013;6(5): 596-606.

120. Edwards RA, Witherspoon M, Wang K, et al. Epigenetic repression of DNA mismatch repair by inflammation and hypoxia in inflammatory bowel disease-associated colorectal cancer. Cancer Res. 2009;69(16): 6423-6429.

121. Chang CL, Marra G, Chauhan DP, et al. Oxidative stress inactivates the human DNA mismatch repair system. Am J Physiol Cell Physiol. 2002;283(1):C148-C154.

122. Colotta F, Allavena P, Sica A, Garlanda C, Mantovani A. Cancer-related inflammation, the seventh hallmark of cancer: links to genetic instability. Carcinogenesis. 2009;30(7):1073-1081.
123. Chen DF, Gong BD, Xie Q, Ben QW, Liu J, Yuan YZ. MicroRNA155 is induced in activated CD4(+) T cells of TNBS-induced colitis in mice. World J Gastroenterol. 2010;16(7):854-861.

124. Zhang X, Li M, Zuo K, et al. Upregulated miR-155 in papillary thyroid carcinoma promotes tumor growth by targeting APC and activating Wnt/beta-catenin signaling. J Clin Endocrinol Metab. 2013;98(8):E1305-E1313.

125. Sheehan KM, Sheahan K, O'Donoghue DP, et al. The relationship between cyclooxygenase-2 expression and colorectal cancer. JAMA. 1999;282(13):1254-1257.

126. Castellone MD, Teramoto H, Williams BO, Druey KM, Gutkind JS. Prostaglandin E2 promotes colon cancer cell growth through a Gs-axin-beta-catenin signaling axis. Science. 2005;310(5753): 1504-1510.

127. Half E, Arber N. Colon cancer: preventive agents and the present status of chemoprevention. Expert Opin Pharmacother. 2009;10(2): 211-219.

128. Jones MK, Wang H, Peskar BM, et al. Inhibition of angiogenesis by nonsteroidal anti-inflammatory drugs: insight into mechanisms and implications for cancer growth and ulcer healing. Nat Med. 1999;5(12):1418-1423.

129. Tessner TG, Muhale F, Riehl TE, Anant S, Stenson WF. Prostaglandin E2 reduces radiation-induced epithelial apoptosis through a mechanism involving AKT activation and bax translocation. J Clin Invest. 2004;114(11):1676-1685.

130. Oshima M, Dinchuk JE, Kargman SL, et al. Suppression of intestinal polyposis in Apc delta716 knockout mice by inhibition of cyclooxygenase 2 (COX-2). Cell. 1996;87(5):803-809.

131. Chulada PC, Thompson MB, Mahler JF, et al. Genetic disruption of Ptgs-1, as well as Ptgs-2, reduces intestinal tumorigenesis in Min mice. Cancer Res. 2000;60(17):4705-4708.

132. Chen LC, Hao CY, Chiu YS, et al. Alteration of gene expression in normal-appearing colon mucosa of APC(min) mice and human cancer patients. Cancer Res. 2004;64(10):3694-3700.

133. Haertel-Wiesmann M, Liang Y, Fantl WJ, Williams LT. Regulation of cyclooxygenase-2 and periostin by Wnt-3 in mouse mammary epithelial cells. J Biol Chem. 2000;275(41):32046-32051.

134. Howe LR, Subbaramaiah K, Chung WJ, Dannenberg AJ, Brown AM. Transcriptional activation of cyclooxygenase-2 in Wnt-1-transformed mouse mammary epithelial cells. Cancer Res. 1999;59(7): $1572-1577$.

135. McClellan JL, Davis JM, Steiner JL, et al. Intestinal inflammatory cytokine response in relation to tumorigenesis in the $\operatorname{Apc}(\mathrm{Min} /+)$ mouse. Cytokine. 2012;57(1):113-119.

136. Reichling T, Goss KH, Carson DJ, et al. Transcriptional profiles of intestinal tumors in Apc(Min) mice are unique from those of embryonic intestine and identify novel gene targets dysregulated in human colorectal tumors. Cancer Res. 2005;65(1):166-176.

137. Grivennikov SI, Wang K, Mucida D, et al. Adenoma-linked barrier defects and microbial products drive IL-23/IL-17-mediated tumour growth. Nature. 2012;491(7423):254-258.

138. Zeineldin M, Miller MA, Sullivan R, Neufeld KL. Nuclear adenomatous polyposis coli suppresses colitis-associated tumorigenesis in mice. Carcinogenesis. 2014;35(8):1881-1890.

139. Yoshimi K, Tanaka T, Takizawa A, et al. Enhanced colitis-associated colon carcinogenesis in a novel Apc mutant rat. Cancer Sci. 2009; 100(11):2022-2027.

140. Barker N, Ridgway RA, van Es JH, et al. Crypt stem cells as the cellsof-origin of intestinal cancer. Nature. 2009;457(7229):608-611.

141. Leow CC, Polakis P, Gao WQ. A role for Hath1, a bHLH transcription factor, in colon adenocarcinoma. Ann N Y Acad Sci. 2005;1059: 174-183.

142. Velcich A, Yang W, Heyer J, et al. Colorectal cancer in mice genetically deficient in the mucin Muc2. Science. 2002;295(5560):1726-1729.

143. Wenzel UA, Magnusson MK, Rydstrom A, et al. Spontaneous colitis in Muc2-deficient mice reflects clinical and cellular features of active ulcerative colitis. PLoS One. 2014;9(6):e100217. 
144. Yang K, Popova NV, Yang WC, et al. Interaction of Muc 2 and Apc on Wnt signaling and in intestinal tumorigenesis: potential role of chronic inflammation. Cancer Res. 2008;68(18):7313-7322.

145. van Es JH, van Gijn ME, Riccio O, et al. Notch/gamma-secretase inhibition turns proliferative cells in intestinal crypts and adenomas into goblet cells. Nature. 2005;435(7044):959-963.

146. Spears E, Neufeld KL. A novel double-negative feedback loop between adenomatous polyposis coli and musashi1 in colon epithelia. $\mathrm{J}$ Biol Chem. 2011;286(7):4946-4950.

147. Imai T, Tokunaga A, Yoshida T, et al. The neural RNA-binding protein Musashi1 translationally regulates mammalian numb gene expression by interacting with its mRNA. Mol Cell Biol. 2001;21(12): 3888-3900.

148. Li D, Peng X, Yan D, et al. Msi-1 is a predictor of survival and a novel therapeutic target in colon cancer. Ann Surg Oncol. 2011;18(7): 2074-2083.

149. Femia AP, Giannini A, Fazi M, et al. Identification of mucin depleted foci in the human colon. Cancer Prev Res (Phila). 2008;1(7): 562-567.

150. Caderni G, Femia AP, Giannini A, et al. Identification of mucin-depleted foci in the unsectioned colon of azoxymethane-treated rats: correlation with carcinogenesis. Cancer Res. 2003;63(10):2388-2392.

151. Femia AP, Dolara P, Giannini A, Salvadori M, Biggeri A, Caderni G. Frequent mutation of Apc gene in rat colon tumors and mucin-depleted foci, preneoplastic lesions in experimental colon carcinogenesis. Cancer Res. 2007;67(2):445-449.

152. Femia AP, Luceri C, Soares PV, Lodovici M, Caderni G. Multiple mucin depleted foci, high proliferation and low apoptotic response in the onset of colon carcinogenesis of the PIRC rat, mutated in Apc. Int J Cancer. Epub September 25, 2014.

153. Breitman M, Zilberberg A, Caspi M, Rosin-Arbesfeld R. The armadillo repeat domain of the APC tumor suppressor protein interacts with Striatin family members. Biochim Biophys Acta. 2008;1783(10): 1792-1802.

154. Miwa N, Furuse M, Tsukita S, Niikawa N, Nakamura Y, Furukawa Y. Involvement of claudin-1 in the beta-catenin/Tcf signaling pathway and its frequent upregulation in human colorectal cancers. Oncol Res. 2001;12(11-12):469-476.

155. Yoshimi K, Tanaka T, Serikawa T, Kuramoto T. Tumor suppressor APC protein is essential in mucosal repair from colonic inflammation through angiogenesis. Am J Pathol. 2013;182(4):1263-1274.

156. Munemitsu S, Souza B, Muller O, Albert I, Rubinfeld B, Polakis P. The APC gene product associates with microtubules in vivo and promotes their assembly in vitro. Cancer Res. 1994;54(14):3676-3681.

157. Van Itallie CM, Anderson JM. Architecture of tight junctions and principles of molecular composition. Semin Cell Dev Biol. 2014;36C: $157-165$.

158. Hinck L, Nathke I. Changes in cell and tissue organization in cancer of the breast and colon. Curr Opin Cell Biol. 2014;26:87-95.

159. Du Q, Park KS, Guo Z, et al. Regulation of human nitric oxide synthase 2 expression by Wnt beta-catenin signaling. Cancer Res. 2006;66(14):7024-7031.

160. Serban DE. The gut microbiota in the metagenomics era: sometimes a friend, sometimes a foe. Roum Arch Microbiol Immunol. 2011;70(3) 134-140.

161. Qin J, Li R, Raes J, et al. A human gut microbial gene catalogue established by metagenomic sequencing. Nature. 2010; 464(7285):59-65.

162. Willing B, Halfvarson J, Dicksved J, et al. Twin studies reveal specific imbalances in the mucosa-associated microbiota of patients with ileal Crohn's disease. Inflamm Bowel Dis. 2009;15(5):653-660.

163. Klag T, Stange EF, Wehkamp J. Defective antibacterial barrier in inflammatory bowel disease. Dig Dis. 2013;31(3-4):310-316.

164. Wrzosek L, Miquel S, Noordine ML, et al. Bacteroides thetaiotaomicron and Faecalibacterium prausnitzii influence the production of mucus glycans and the development of goblet cells in the colonic epithelium of a gnotobiotic model rodent. BMC Biol. 2013;11:61.
165. Petersson J, Schreiber O, Hansson GC, et al. Importance and regulation of the colonic mucus barrier in a mouse model of colitis. Am J Physiol Gastrointest Liver Physiol. 2011;300(2):G327-G333.

166. Gaudier E, Rival M, Buisine MP, Robineau I, Hoebler C. Butyrate enemas upregulate Muc genes expression but decrease adherent mucus thickness in mice colon. Physiol Res. 2009;58(1):111-119.

167. Zen Y, Harada K, Sasaki M, et al. Lipopolysaccharide induces overexpression of MUC2 and MUC5AC in cultured biliary epithelial cells: possible key phenomenon of hepatolithiasis. Am J Pathol. 2002; 161(4):1475-1484.

168. Burger-van Paassen N, Vincent A, Puiman PJ, et al. The regulation of intestinal mucin MUC2 expression by short-chain fatty acids: implications for epithelial protection. Biochem J. 2009;420(2):211-219.

169. Hatayama H, Iwashita J, Kuwajima A, Abe T. The short chain fatty acid, butyrate, stimulates MUC2 mucin production in the human colon cancer cell line, LS174T. Biochem Biophys Res Commun. 2007;356(3): 599-603.

170. Jensen TK, Boye M, Moller K, Leser TD, Jorsal SE. Association of Serpulina hyodysenteriae with the colonic mucosa in experimental swine dysentery studied by fluorescent in situ hybridization. APMIS. 1998;106(11):1061-1068.

171. Strauss J, Kaplan GG, Beck PL, et al. Invasive potential of gut mucosaderived Fusobacterium nucleatum positively correlates with IBD status of the host. Inflamm Bowel Dis. 2011;17(9):1971-1978.

172. Hansson GC, Johansson ME. The inner of the two Muc2 mucindependent mucus layers in colon is devoid of bacteria. Gut Microbes. 2010;1(1):51-54

173. Ivanov II, Atarashi K, Manel N, et al. Induction of intestinal Th17 cells by segmented filamentous bacteria. Cell. 2009;139(3):485-498

174. Round JL, Lee SM, Li J, et al. The Toll-like receptor 2 pathway establishes colonization by a commensal of the human microbiota. Science. 2011;332(6032):974-977.

175. Arpaia N, Campbell C, Fan X, et al. Metabolites produced by commensal bacteria promote peripheral regulatory T-cell generation. Nature. 2013;504(7480):451-455.

176. Furusawa Y, Obata Y, Fukuda S, et al. Commensal microbe-derived butyrate induces the differentiation of colonic regulatory $\mathrm{T}$ cells. Nature. 2013;504(7480):446-450.

177. Kostic AD, Chun E, Robertson L, et al. Fusobacterium nucleatum potentiates intestinal tumorigenesis and modulates the tumor-immune microenvironment. Cell Host Microbe. 2013;14(2):207-215.

178. Rubinstein MR, Wang X, Liu W, Hao Y, Cai G, Han YW. Fusobacterium nucleatum promotes colorectal carcinogenesis by modulating E-cadherin/beta-catenin signaling via its FadA adhesin. Cell Host Microbe. 2013;14(2):195-206.

179. Rakoff-Nahoum S, Medzhitov R. Regulation of spontaneous intestinal tumorigenesis through the adaptor protein MyD88. Science. 2007;317(5834):124-127.

180. Salcedo R, Worschech A, Cardone M, et al. MyD88-mediated signaling prevents development of adenocarcinomas of the colon: role of interleukin 18. J Exp Med. 2010;207(8):1625-1636.

181. Dennis KL, Wang Y, Blatner NR, et al. Adenomatous polyps are driven by microbe-instigated focal inflammation and are controlled by IL-10producing T cells. Cancer Res. 2013;73(19):5905-5913.

182. Huycke MM, Moore D, Joyce W, et al. Extracellular superoxide production by Enterococcus faecalis requires demethylmenaquinone and is attenuated by functional terminal quinol oxidases. Mol Microbiol. 2001;42(3):729-740.

183. Huycke MM, Abrams V, Moore DR. Enterococcus faecalis produces extracellular superoxide and hydrogen peroxide that damages colonic epithelial cell DNA. Carcinogenesis. 2002;23(3):529-536.

184. Huycke MM, Moore DR. In vivo production of hydroxyl radical by Enterococcus faecalis colonizing the intestinal tract using aromatic hydroxylation. Free Radic Biol Med. 2002;33(6):818-826.

185. Lara-Tejero M, Galan JE. Cytolethal distending toxin: limited damage as a strategy to modulate cellular functions. Trends Microbiol. 2002;10(3):147-152. 
186. Wu S, Morin PJ, Maouyo D, Sears CL. Bacteroides fragilis enterotoxin induces c-Myc expression and cellular proliferation. Gastroenterology. 2003;124(2):392-400.

187. Deplancke B, Finster K, Graham WV, Collier CT, Thurmond JE, Gaskins HR. Gastrointestinal and microbial responses to sulfatesupplemented drinking water in mice. Exp Biol Med. 2003;228(4): 424-433.

188. Zhang H, Moochhala SM, Bhatia M. Endogenous hydrogen sulfide regulates inflammatory response by activating the ERK pathway in polymicrobial sepsis. J Immunol. 2008;181(6):4320-4331.

189. Maggio-Price L, Treuting P, Zeng W, Tsang M, Bielefeldt-Ohmann H, Iritani BM. Helicobacter infection is required for inflammation and colon cancer in SMAD3-deficient mice. Cancer Res. 2006;66(2): 828-838

190. Garrett WS, Punit S, Gallini CA, et al. Colitis-associated colorectal cancer driven by T-bet deficiency in dendritic cells. Cancer cell. 2009; 16(3):208-219.

191. Uronis JM, Muhlbauer M, Herfarth HH, Rubinas TC, Jones GS, Jobin C. Modulation of the intestinal microbiota alters colitis-associated colorectal cancer susceptibility. PLoS One. 2009;4(6):e6026.

192. Elinav E, Strowig T, Kau AL, et al. NLRP6 inflammasome regulates colonic microbial ecology and risk for colitis. Cell. 2011;145(5): $745-757$.
193. Hu B, Elinav E, Huber S, et al. Microbiota-induced activation of epithelial IL-6 signaling links inflammasome-driven inflammation with transmissible cancer. Proc Natl Acad Sci U S A. 2013;110(24): 9862-9867.

194. Couturier-Maillard A, Secher T, Rehman A, et al. NOD2-mediated dysbiosis predisposes mice to transmissible colitis and colorectal cancer. J Clin Invest. 2013;123(2):700-711.

195. Zeineldin M, Jensen D, Paranjape SR, et al. Human cancer xenografts in outbred nude mice can be confounded by polymorphisms in a modifier of tumorigenesis. Genetics. 2014;197(4):1365-1376.

196. Cormier RT, Hong KH, Halberg RB, et al. Secretory phospholipase Pla2g2a confers resistance to intestinal tumorigenesis. Nat Genet. 1997;17(1):88-91.

197. Fijneman RJ, Peham JR, van de Wiel MA, et al. Expression of $\mathrm{Pla} 2 \mathrm{~g} 2 \mathrm{a}$ prevents carcinogenesis in Muc2-deficient mice. Cancer Sci. 2008;99(11):2113-2119.

198. Dove WF, Clipson L, Gould KA, et al. Intestinal neoplasia in the ApcMin mouse: independence from the microbial and natural killer (beige locus) status. Cancer Res. 1997;57(5):812-814.

199. Colnot S, Niwa-Kawakita M, Hamard G, et al. Colorectal cancers in a new mouse model of familial adenomatous polyposis: influence of genetic and environmental modifiers. Lab Invest. 2004;84(12): 1619-1630.

\section{Publish your work in this journal}

Gastrointestinal Cancer: Targets and Therapy is an international, peer-reviewed, open access journal focusing on gastro-intestinal cancer research, identification of therapeutic targets and the optimal use of preventative and integrated treatment interventions to achieve improved outcomes, enhanced survival and quality of life for the

\section{Dovepress}

cancer patient. The manuscript management system is completely online and includes a very quick and fair peer-review system. Visit http://www.dovepress.com/testimonials.php to read real quotes from published authors. 